\title{
Assessment of Effectiveness of Small Group Discussion As A Teaching Tool for A Session of Clinico- Social Case Study.
}

\author{
Dr.Yalamanchili Venkata Lakshmi ${ }^{1}$, Dr.Paineni Sujitha Devi ${ }^{2}$ \\ ${ }^{I}$ Department Of Community Medicine,Sri Venkateswara Medical College,India. \\ ${ }^{2}$ Sri Venkateswara Medical College,India.
}

\begin{abstract}
Medical education has always been the cornerstone of improvement of community health by producing right doctors who can deliver best of science and best of care. One of the methods that evolved in teaching community medicine is Clinico- social case study. It is akin to Clinical case study in clinical subjects, except for its gives a broader perspective to the medical student regarding disease syndrome i.e., the social bearer of disease, helping them to be a complete physician. Lately the students are falling into the rut of being passively involved in the discussion when a single student is presenting the case, in regular pedagogical method. Current study done group discussion on CSCS- TB aims to break through that barrier, involves all of the students into the discussion with a knowledgeable teacher being their leader.It shifts the base from what to learn to how to learn.The feedback received was quite impressive and heralds a new light to different mode of teaching .
\end{abstract}

Keywords: clinico- social case study, learning effectiveness, small group discussion,teaching method.

\section{Introduction}

Right Physician of health care of the future is produced by right kind of medical training.In short,the medical education should aim for balance of scientific knowledge and biologic understanding, clinical reasoning and practical skill, and the development of character, compassion, and integrity, in a complete package[1]. Everything of above only comes when the medical students are treated as future doctors and not serial test takers. It is absolutely possible only when the medical students think actively and learn actively.In the recent days, its always about the "next test" i.e., what is to be learnt, instead of what is being exactly taught and how it is to be learnt.This seriously is leading to infamous binge-purge of heaps of medical information into the tests,never converting it into knowledge.This situation calls for utilizing different teaching methods and modalities in medical education.[2]

Clinico-Social Case Study forms a major part of curriculum as well as a tool for medical student's understanding and application of knowledge in a broader aspect of disease syndrome rather than just the disease, i.e., it aims for making students aware of social bearer of a disease, helping them to be a complete physician. In the present study, we undertook group discussion on clinico- social case study of tuberculosis with 2 small groups of medical students.Thus shifting emphasis from teaching students "what to learn" to "how to learn".

\section{Objectives}

To assess effectiveness of group discussion as a teaching method based on the feedback received from students.

\subsection{Study design}

\section{Methodology}

A cross sectional study on assessing effectiveness of group discussion as a teaching method in clinic social case study- Tuberculosis

\subsection{Method followed:}

A planned group discussion with 2 groups with 25 students each, who are in 7th semester M.B.,B.S., .The discussion based on TB- clinico- social case study,with two of us as the leaders for the session for each of the group.

They were told of the topic related learning objectives during briefing and were advised to prepare for the following day discussion session with not just the standard textbook but with other available resources as well.On the day of discussion, they were sent to the wards to take a clinico-social cases and were advised to get back with in an hour of time.As they got back..they were given a small break to settle down,during which we made sure that everyone is comfortable enough to shred the ice of authority of a faculty member in front of 
them. So that each and everyone can express their views and thoughts and ideas without the fear of judgment and critical assessment.

All through the session, we were keen on making everyone,especially the shy and no attention seekers to be able to tell what they want to.we were also keen on not letting the discussion go ajar from the topic[3].The discussion had been a breeze with very co-operative students.

\subsection{Data Collection}

At the end of the session, Feedback forms were given to them to fill up anonymously.

\subsection{Data analysis}

All the data is processed and sorted by MS Excel.

\section{Results}

\begin{tabular}{|l|l|l|}
\hline FEEDBACK(ASSESSMENT) & YES(\%) & NO(\%) \\
\hline Adequate initial briefing & 50 & 50 \\
\hline Encouragement to participate actively & 100 & 0 \\
\hline Facilitating active exchange of ideas & 90 & 10 \\
\hline $\begin{array}{l}\text { Interest and enthusiasm towards the } \\
\text { discussion }\end{array}$ & 80 & 20 \\
\hline \begin{tabular}{l} 
Steering the discussion on right path \\
\hline $\begin{array}{l}\text { Filling the voids of knowledge and clearing } \\
\text { misconceptions }\end{array}$
\end{tabular} & 94 & 10 \\
\hline Patience in dealing with disagreements & 96 & 6 \\
\hline Cutting personal comments when needed & 90 & 4 \\
\hline $\begin{array}{l}\text { Whether the learning objectives have been } \\
\text { reached by the end of session or not? }\end{array}$ & 96 & 10 \\
\hline $\begin{array}{l}\text { Whether they thought that going in the } \\
\text { traditional way could have been more useful } \\
\text { for them to understand the topic? }\end{array}$ & 0 & 4 \\
\hline $\begin{array}{l}\text { Whether they want to have similar sessions } \\
\text { on other topics as well in the future or not? }\end{array}$ & 100 & 200 \\
\hline $\begin{array}{l}\text { Whether the session helped them in effective } \\
\text { learning of the topic? }\end{array}$ & 98 & 2 \\
\hline $\begin{array}{l}\text { Are they confident in recall of the essential } \\
\text { concepts learnt in the session? }\end{array}$ & 98 & 0 \\
\hline
\end{tabular}

IV.1

Satisfaction after the class
\begin{tabular}{|l|l|l|}
\hline Satisfaction after the class( Likert Scale) & no. of students & percentage \\
\hline 1-not satisfied at all & 0 & 0 \\
\hline 2-not satisfied & 0 & 0 \\
\hline 3-neutral & 2 & 4 \\
\hline 4-satisfied & 12 & 24 \\
\hline 5-very satisfied & 36 & 78 \\
\hline
\end{tabular}

\section{Discussion}

At our department it's been a teaching routine of pedagogical method based presentation of every clinico-social case written by a particular student with on the spot guidance from a skilled faculty member. But as they say, routine kills the ability to think actively and learn pro actively,so did the students get accustomed to 
rote pattern of come-headnod-go. And thus we find their performance and understanding of few major concepts in subsequent exams/situations not up to the mark.

On further thought, the standard text book that is followed here being K.Park's Textbook of Preventive and Social Medicine, which serves as both the primary and secondary textual source for majority of students, i.e., for basic understanding and also as a study material for appearing in university examinations. In general, a secondary textual resource could be readily assimilated while a primary textual resource doesn't come pre digested - it needs to be thought over,discussed about and must be worked on to get a grip over subject. The tricky part is, to utilise secondary text sources efficiently, one must have good command on primary ones[4]. Once they get to know this, and act to first learn the subject through primary standard textbooks, they will know what to pick up and what to not and how represent their knowledge in broader realms of daily life and their clinical practice, not just in the exam.

From the above feedback,we have learnt that the students very much liked group discussion strategy in teaching them and accepted it helps them learn better than oral presentation by single student and random questions in between-the traditional strategy till date. We've also learnt that we should have done a little more of briefing as it helps in getting the basic idea or overview of the topic. Well, by the end of the discussion, to be honest, we got the perspective from the students' side which served as a learning tool for improving ourselves as medical educators.

\section{Conclusion}

The results of the study are pretty impressive and call for employing various kinds of teaching methods for developing the zeal to learn more ,than to score more in the medical students[5]. As the study ends, we recommend that the results of the study have to be discussed with the higher authority and other faculty members in getting the change in teaching strategy of CS-CS. Even then,not to make it an yet another routine, periodically deviate from it and use other teaching strategies and test them depending on the topic. End of scheduled rotation assessment has to be planned for every batch so that they also get the examination dynamics and self check of understanding apart from proper knowledge and command in its application.

\section{Acknowledgment}

We thank the HOD of the Department of Community Medicine, SVMC., and the staff and postgraduate students for helping us to conduct the study and all the wonderful students who enthusiastically participated in the study.

\section{References}

[1]. A New Series on Medical Education - NEJM. (2016). New England Journal of Medicine., from http://www.nejm.org/doi/full/10.1056/NEJMe068211

[2]. J. Barrett, L. Yates, G. McColl. Medical teachers conceptualize a distinctive form of clinical knowledge., Advances in Health Sciences Education 20(2015), 355-369

[3]. N.Anantkrishnan,K.R.Sethuraman,Santhosh Kumar, Medical Education: Principles and Practice (Pondicherry,IND:AANTTC, 2000)

[4]. Knowles MS. The modern practice of adult education. Andragogy versus Pedagogy. (New York: Association Press, 1970.)

[5]. Flexner, A Medical education in the United States and Canada. A report to the Carnegie Foundation for the Advancement of Teaching. Bulletin No. 4. Updyke: Boston, Mass; 1910. 